\title{
RANCANG BANGUN SISTEM MONITORING POLUSI UDARA PADA BUDIDAYA TANAMAN SAYUR HIDROPONIK BERBASIS MICROCONTROLLER
}

\author{
Nurul Halizah, Hani Zulfia Zahro', Deddy Rudhistiar \\ Program Studi Teknik Informatika S1, Fakultas Teknologi Industri \\ Institut Teknologi Nasional Malang, Jalan Raya Karanglo km 2 Malang, Indonesia \\ nurulhalizah19@gmail.com
}

\begin{abstract}
ABSTRAK
Polusi udara memberikan dampak yang kurang baik terhadap makhluk hidup, khususnya pada tanaman sayur hidroponik. Akibat dari polusi udara tersebut tanaman dapat mengalami kerusakan bahkan kematian karena terpapar dalam jangka waktu yang cukup lama, sehingga dapat menimbulkan kerugian bagi para petani tanaman sayur hidroponik. Berdasarkan hal tersebut peneliti menggagas alat untuk mendeteksi polusi udara yang terdapat pada tempat penanaman sayur hidroponik, serta sistem monitoring agar bisa dipantau dari jarak jauh oleh pengguna. Penelitian ini merupakan sistim monitoring polusi udara pada tanaman sayur hidroponik berbasis microcontroller Arduino. Metode atau model yang digunakan dalam pengerjaan penelitian ini adalah model waterfall karena harus terstruktur mulai dari proses pertama sampai proses terakhir secara berurutan. Kebutuhan produk pada peneliatian ini mencakup microcontroller Arduino, Sensor MQ-2, Sensor MQ-7, ESP8266, Fan DC 12 V, Led, Buzzer, dan Relay. Hasil penelitian ini adalah produk berupa alat pendeteksi gas, asap dan Co dengan sistem monitoring. Selain mendeteksi, produk yang dibuat memiliki bentuk antisipasi berupa penetralisir udara. Pada website yang dibuat memiliki fitur monitoring untuk melihat data terbaru hasil deteksi sensor, fitur riwayat dapat melihat data - data terdahulu, serta grafik untuk mengetahui tingkat deteksi sensor berdasarkan waktu. Berdasarkan pengujian terhadap sensor dan fitur pada website monitoring polusi udara adalah seluruhnya berjalan dan bekerja dengan baik. Berdasarkan pengujian terhadap pengguna diketahui telah sesuai dengan kebutuhan. Sehingga pada penelitian ini dapat disimpulkan bahwa alat serta website yang dibuat telah bekerja dengan baik dan telah sesuai dengan kebutuhan pengguna.
\end{abstract}

Kata Kunci : Polusi udara, Tanaman hidroponik, Monitoring, IoT

\section{PENDAHULUAN}

Tanaman sayuran bisa saja mengalami kerusakan setelah terpapar oleh konsentrasi yang lebih tinggi dari berbagai polutan di udara. Paparan jangka panjang konsentrasi yang lebih rendah juga dapat menyebabkan kerusakan tanaman. Kerusakan muncul secara bertahap seperti klorosis daun (menguning), nekrosis (kematian), dan membatasi pertumbuhan [1].

Kerusakan tanaman yang disebabkan oleh polusi udara paling umum terjadi di dekat kota-kota besar, pabrik peleburan, kilang, pembangkit listrik, bandara, jalan raya, insinerator, tampat pembuangan sampah. Faktor penyebab luasnya kerusakan oleh polusi udara adalah (1) jenis dan konsentrasi pencemar, (2) jarak dari sumber, (3) lama paparan, dan (4) kondisi meteorologi. Akumulasi zat beracun oleh tanaman mungkin bergantung pada tanaman spesies, sifat tanah dan berbagai faktor lainnya [2].

Tanaman adalah indikator yang baik dari polusi udara dan bertindak sebagai alat untuk mengevaluasi efek polusi yang merupakan bagian dasar dari semua ekosistem dan diidentifikasi sebagai yang paling kuat untuk menerima tekanan yang disebabkan oleh polusi. Polutan dapat memasuki tanaman secara langsung melalui stomata pada daun atau secara tidak langsung melalui tanah yang selama ini diasamkan curah hujan. Sejumlah penelitian menunjukkan bahwa polusi udara dapat mengubah proses fisiologis dan biokimia tanaman, sehingga mempengaruhi pertumbuhan.
Polusi udara dapat merusak kutikula daun dan mempengaruhi konduktansi stomata, sistem fotosintesis, umur panjang daun dan pola asimilasi karbon di dalam tumbuhan. Tingkat cedera atau kerusakan tergantung pada konsentrasi gas pada atmosfer, durasi paparan dan kondisi lingkungan yang ada. Terlepas dari efek merugikan dari polutan ini, hanya ada sedikit laporan tentang tanaman yang tahan polusi . Tanaman berperan penting dalam memantau dan menjaga keseimbangan ekologi [3].

Dari penjelasan sebelumnya tercipta suatu pemikiran untuk mengetahui kondisi udara yang diterapkan pada suatu simulasi miniatur tempat budidaya sayur hidroponik. Dimana terdapat Sensor MQ-2 berfungsi untuk mendeteksi banyak sedikitnya kadar gas/asap yang ada pada miniatur, serta Sensor MQ-7 yang berfungsi untuk mendeteksi banyak sedikitnya kadar co yang ada pada miniatur dan terdapat kipas mengarah ke luar ruangan untuk mengeluarakan asap,gas dan co.

\section{TINJAUAN PUSTAKA}

\subsection{Penelitian Terdahulu}

Pada tahun 2018 Liandy melakukan penelitian tentang pemantauan gas berbahaya pada sebuah ruangan. Sistem tersebut melakukan monitoring pada sebuah ruangan untuk mengetahui tingkat pencemaran udara menggunakan IP Cam, serta hasil deteksi sensor yang ditampilkan pada website [4]. 
Berdasarkan penelitian yang dilakukan Shoma pada tahun 2020, penelitian tersebut tentang bagaimana kadar asap dan gas mempengaruhi perputaran kipas dengan menerapkan logika fuzzy. Dibantu menggunakan perangkat sensor, salah satunya Sensor MQ-2 yang dihubungkan dengan mikrokontroler untuk mengetahui datanya[5].

Tahun 2019 Karisma dkk melakukan sebuah penelitian bagaimana memberi informasi mengenai tingkat polusi udara apakah semakin meningkat atau berkurang, dan dapat merekam data kualitas udara melalui Internet of Things. Penelitian ini menggunakan sensor polusi yaitu sensor MQ-7 dan kamera web untuk mengetahui tingkat polusi udara dan aktivitas gerakan di lingkungan sekitar kostkostan. Data yang telah diperoleh akan dikirim melalui mikrokontroler Arduino [6].

Ditahun yang sama Putra dkk juga melakukan sebuah penelitian pemantauan kualitas udara terhadap gas $\mathrm{CO}$ dan $\mathrm{CO} 2$ berbasis Internet Of Things. Data yang dikirim menggunakan mikrokontroler Wemos D1 dan ditampilkan menggunakan LCD 16x2[7].

Pada tahun 2017 Handayani dkk melakukan penelitian untuk mengukur kadar karbon moniksida pada Kota Dumai yang kerap kali diselimuti kabut asap akibat kebakaran hutan. Sistem monitoring yang dibantu menggunakan perangkat Sensor MQ-7 dan mikrokontroler arduino serta data yang dideteksi oleh sensor akan ditampilkan pada sebuah website[8].

\subsection{Internet Of Things (IoT)}

Internet of Things (IoT) memungkinkan kita terhubung kapan saja, di mana saja dan untuk apa saja. Internet of Things juga dapat dianggap sebagai jaringan luas yang memungkinkan terjadinya komunikasi antara manusia ke manusia, manusia-kebenda dan benda ke benda. Ada banyak kegunaan dari aplikasi IoT dalam beberapa aspek termasuk medis, manufaktur, industri, transportasi, pendidikan, pemerintahan, pertambangan, habitat dan sebagainya. IoT menggambarkan dimana hampir semua hal dapat dihubungkan dan berkomunikasi dengan cara yang cerdas dari sebelumnya.

\subsection{Arduino}

Arduino Uno adalah board mikrokontroler berbasis ATMega328. Memiliki 14 pin input dari output digital dimana 6 pin input tersebut dapat digunakan sebagai output PWM (Pulse Widht Modulation) dan 6 pin input analog, $16 \mathrm{MHz}$ osilator kristal, koneksi USB, jack power, ICSP header, dan tombol reset. Untuk mendukung mikrokontroler agar dapat digunakan, cukup hanya menghubungkan board Arduino Uno ke komputer dengan menggunakan kabel USB dan AC adaptor sebagai suplay atau baterai untuk menjalankannya. Kelebihan Arduino diantaranya adalah tidak perlu perangkat chip programmer karena di dalamnya sudah ada bootloader yang akan menangani upload program dari komputer, Arduino sudah memiliki sarana komunikasi USB, sehingga pengguna laptop yang tidak memiliki port serial/RS323 bisa menggunakannya.

\subsection{Sensor MQ-7}

Sensor MQ-7 merupakan sensor gas karbon monoksida (CO) yang berfungsi untuk mengukur konsentrasi gas karbon monoksida (CO). Sensor ini memiliki sensitivitas tinggi dan 10 waktu respon yang cepat. Keluaran yang dihasilkan oleh sensor ini adalah berupa sinyal analog. Sensor ini juga membutuhkan tegangan direct current (DC) sebesar 5V. Sensor ini mampu mendeteksi kadar nilai karbon monoksida dalam udara dengan cakupan antara 20-2000 ppm.

\subsection{Sensor MQ-2}

Sensor jenis ini adalah alat yang digunakan untuk mendeteksi konsentrasi gas yang mudah terbakar di udara serta asap dan output membaca sebagai tegangan analog. Sensor gas asap MQ-2 dapat langsung diatur sensitifitasnya dengan memutar trimpotnya. Gas yang dapat dideteksi diantaranya : LPG, i-butane, propane, methane, alcohol, Hydrogen, smoke. Berikut spesifikasi dari alat tersebut : Catu daya pemanas : $5 \mathrm{~V}$ AC/DC, Catu daya rangkaian : 5V DC, Range pengukuran : $200-5000 \mathrm{ppm}$ untuk LPG, propane 300 - 5000 ppm untuk butane 5000 - 20000 ppm untuk methane $300-5000$ ppm untuk Hidrogen. Keluaran : analog (perubahan tegangan).

\section{METODE PENELITIAN}

\subsection{Desain Arsitektur Sistem}

Pada desain arsitektur sistem terrdapat 3 tahapan yaitu : input, proses dan output.

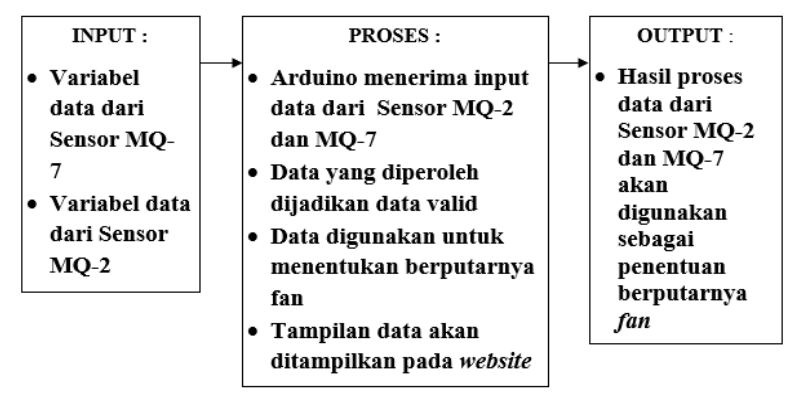

Gambar 1 Arsitektur Sistem

\subsection{Desain Rangkaian}

Perangkat yang digunakan dalam pembuatan sistem terdiri dari : Arduino uno, Relay, Buzzer, LED, Fan $12 \mathrm{~V}$, Sensor MQ-7, Sensor MQ-2 dan ESP 8266. Desain rangkaian ditunjukkan pada Gambar 2. 


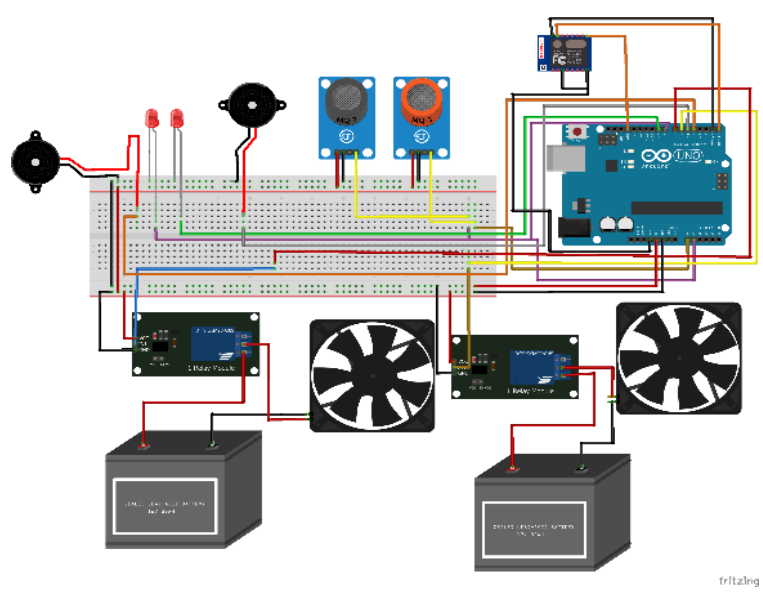

Gambar 2 Desain Rangkaian

\subsection{Blok Diagram Sistem}

Sistem monitoring ini menggunakan sistem minimum arduino, dimana Arduino digunakan untuk mengontrol beberapa komponen yang digunakan seperti fan, buzzer, sensor MQ2, sensor MQ 7, dan LED. Sistem ini bekerja dengan membaca kadar gas, kadar asap dan kemudian data yang di dapatkan tersebut akan dikirimkan ke database melalui ESP8266 untuk disimpan ke database yang kemudian ditampilkan pada website. Website dapat menampilkan informasi apabila ada koneksi internet dimana informasi yang akan ditampilkan nantinya berupa data realtime dari pembacaan sensor MQ-7 dan sensor MQ-2. Blok diagram ditunjukkan pada Gambar 3.

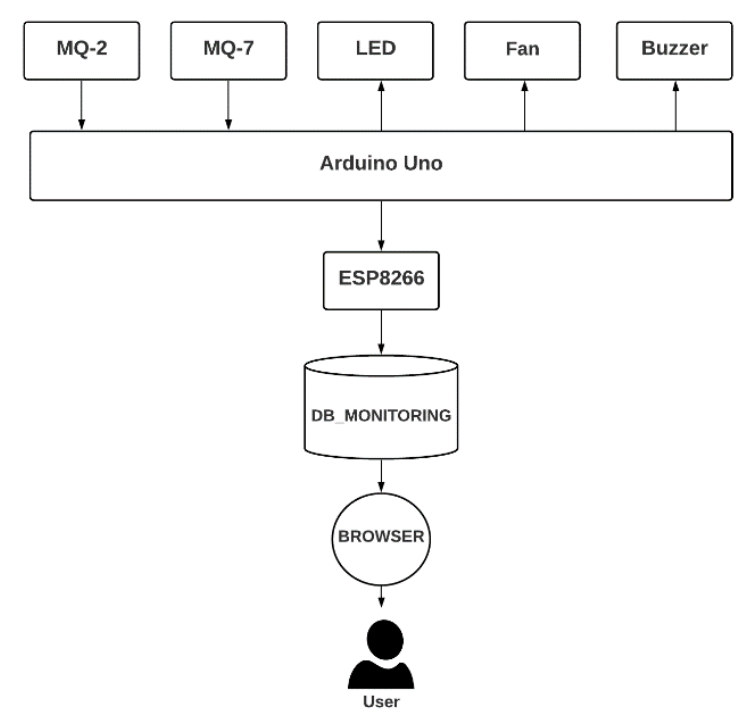

Gambar 3 Blok diagram sistem

\subsection{Flowchart Sistem}

Flowchart sistem ini menjelaskan proses berjalananya aplikasi seperti ditunjukkan pada Gambar 4.

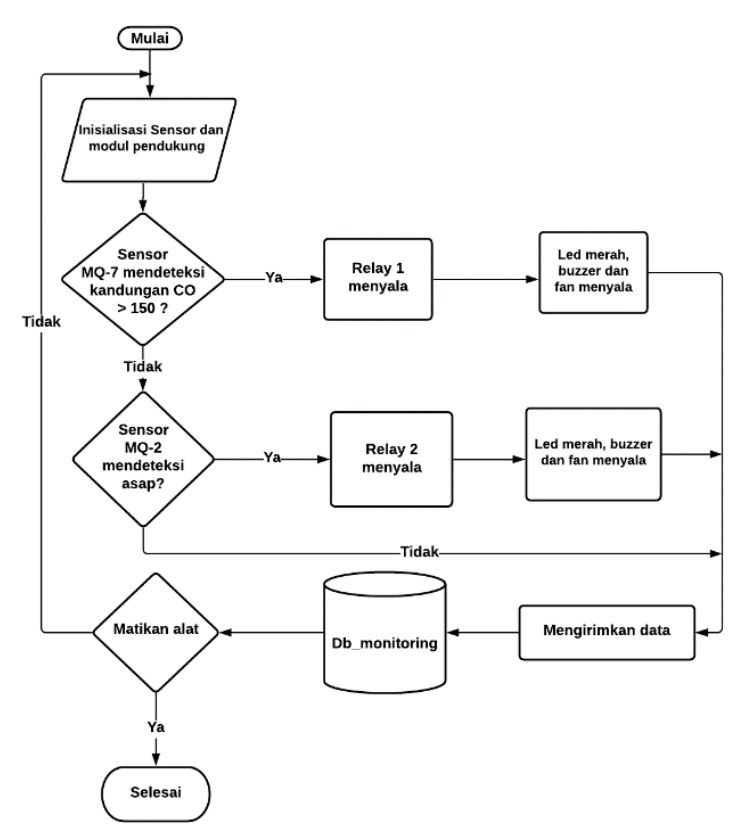

Gambar 4 Flowchart Sistem

Pada flowchart di atas sistem dimulai dengan inisialisasi sensor dan modul pendukung, kemudian sensor MQ-7 akan mendeteksi kandungan CO yang terdapat pada miniatur, jika kandungan $\mathrm{CO}$ lebih dari 200 maka led, buzzer dan fan akan menyala. Begitu juga pada sensor MQ-2 jika mendeteksi adanya asap maka led, buzzer dan fan juga menyala dan data yang telah didapat oleh Sensor MQ-7 dan Sensor MQ-2 akan dikirimkan ke database monitoring. Data yang diperoleh akan dikirim ke website secara realtime oleh microcontroller.

\section{HASIL DAN PEMBAHASAN}

4.1. Pengujian Hardware

Pengujian seluruh komponen yang sudah terkoneksi, meliputi : Arduino Uno, Sensor MQ-7, Sensor MQ-2 dan ESp 8266

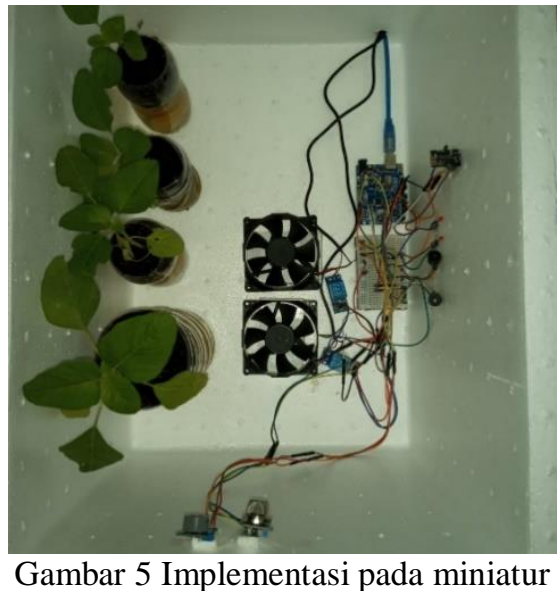

Gambar 5 merupakan implementasi penempatan yang telah dijabarkan pada rangkaian alat terhadap miniatur untuk menyimpan tanaman hidroponik. 


\subsection{Pengujian Esp 8266}

Pengujian pada modul ESP8266 atau disebut juga modul wifi ini bertujuan untuk mengetahui lancar atau tidaknya pengiriman data dari sensor ke web server. Untuk mengirim sebuah data, modul ESP8266 harus terkoneksi ke internet terlebih dahulu, koneksi internet dapat mempengaruhi kecepatan pengiriman data dan penerimaan data. Skema rangkaian alat ditunjukkan pada gambar 6 .

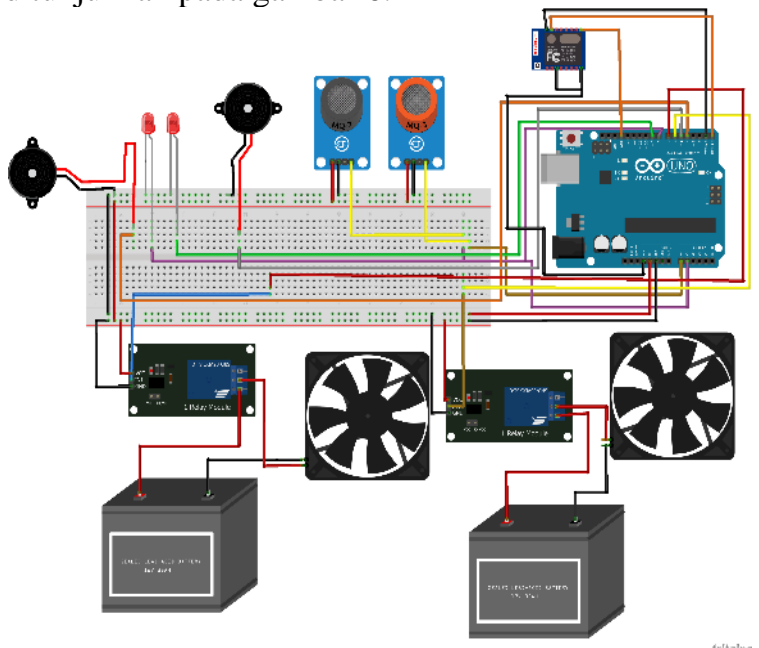

Gambar 6 Rangkaian Sensor

Gambar 6 Merupakan diagram blok atau gambar rangkaian dari sensor yang dihubungkan ke minimum sistem arduino menggunakan kabel jumper. Hasil pembacaan sensor dapat dilihat pada Gambar 7.

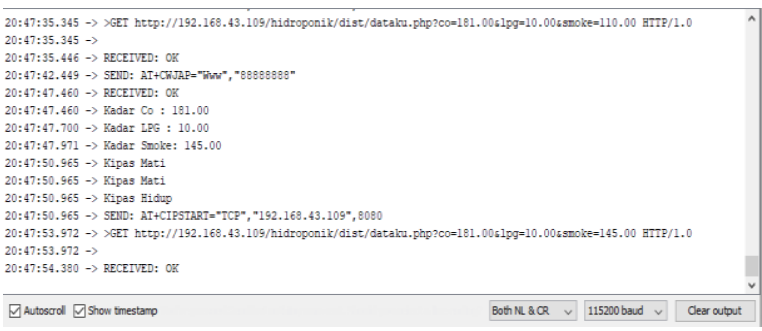

Gambar 7 pembacaan modul esp

Pada Gambar 7 menunjukkan pengujian pengiriman data hasil deteksi sensor menggunakan Esp 8266. Kemudian data disimpan ke database. Data hasil penguijan dapat dilihat pada Tabel 1 .

Tabel 1 Hasil Pengujian Pengiriman data

\begin{tabular}{|c|c|c|c|}
\hline $\begin{array}{c}\text { Pengiriman } \\
\text { Ke }-\end{array}$ & $\begin{array}{c}\text { Terhubung } \\
\text { Ke AP }\end{array}$ & $\begin{array}{c}\text { Terhubung ke } \\
\text { Server }\end{array}$ & $\begin{array}{c}\text { Data Sukses } \\
\text { Dikirim }\end{array}$ \\
\hline 1 & Ya & Ya & Ya \\
\hline 2 & Ya & Ya & Ya \\
\hline 3 & Ya & Ya & Ya \\
\hline 4 & Tidak & Tidak & Tidak \\
\hline 5 & Tidak & Tidak & Tidak \\
\hline 6 & Ya & Tidak & Tidak \\
\hline 7 & Ya & Ya & Ya \\
\hline 8 & Ya & Ya & Ya \\
\hline 9 & Ya & Ya & Ya \\
\hline 10 & Ya & Ya & Ya \\
\hline
\end{tabular}

Terdapat tiga data yang tidak terkirim ke database, biasanya terjadi akibat gagalnya koneksi antara ESP8266 dan Server.

\subsection{Pengujian Sensor MQ-7}

Pengujian Sensor MQ-7 dilakukan dengan cara membandingkan kadar gas yang di deteksi oleh sensor dengan kadar gas yang ditampilkan oleh Combustible Gas Detector 602.

Tabel 2 hasil pengujian sensor MQ-7

\begin{tabular}{|c|c|c|c|c|}
\hline \multirow[b]{2}{*}{ No } & \multicolumn{2}{|c|}{ Hasil baca ppm } & \multirow[b]{2}{*}{ Selisih } & \multirow[b]{2}{*}{$\begin{array}{c}\text { Kesalahan } \\
(\%)\end{array}$} \\
\hline & $\begin{array}{l}\text { Sensor } \\
\text { MQ-7 }\end{array}$ & $\begin{array}{c}\text { Combustible } \\
\text { Gas Detector } \\
602\end{array}$ & & \\
\hline 1 & 355 & 351 & 4 & $1.14 \%$ \\
\hline 2 & 318 & 318 & 0 & $0.00 \%$ \\
\hline 3 & 339 & 333 & 6 & $1.80 \%$ \\
\hline 4 & 317 & 309 & 8 & $2.59 \%$ \\
\hline 5 & 308 & 302 & 6 & $2 \%$ \\
\hline \multicolumn{4}{|c|}{ Rata - rata kesalahan } & $1.50 \%$ \\
\hline
\end{tabular}

Hasil pengujian Sensor MQ-7 menggunakan Combustible Gas Detector 602 diperoleh rata-rata kesalahan sebesar $1.46 \%$ dengan selisih deteksi paling besar pada baris pertama dengan 10 nilai.

\subsection{Pengujian Sensor MQ-2}

Pengujian Sensor MQ-2 dilakukan dengan cara membandingkan kadar gas yang di deteksi oleh sensor dengan kadar gas yang ditampilkan oleh Combustible Gas Detector 602.

Tabel 3 hasil pengujian sensor MQ-2

\begin{tabular}{|c|c|c|c|c|}
\hline \multirow[b]{2}{*}{ No } & \multicolumn{2}{|c|}{ Hasil baca ppm } & \multirow[b]{2}{*}{ Selisih } & \multirow[b]{2}{*}{$\begin{array}{c}\text { Kesalahan } \\
(\%)\end{array}$} \\
\hline & $\begin{array}{l}\text { Sensor } \\
\text { MQ-2 }\end{array}$ & $\begin{array}{c}\text { Combustible } \\
\text { Gas Detector } \\
602\end{array}$ & & \\
\hline 1 & 391 & 381 & 10 & $2.62 \%$ \\
\hline 2 & 321 & 318 & 3 & $0.94 \%$ \\
\hline 3 & 305 & 302 & 3 & $0.99 \%$ \\
\hline 4 & 326 & 321 & 5 & $1.56 \%$ \\
\hline 5 & 340 & 336 & 4 & $1.19 \%$ \\
\hline \multicolumn{4}{|c|}{ Rata - rata kesalahan } & $1.46 \%$ \\
\hline
\end{tabular}

Hasil pengujian Sensor MQ- 2 menggunakan Combustible Gas Detector 602 diperoleh rata-rata kesalahan sebesar $1.50 \%$ dengan selisih deteksi paling besar pada baris ke - 4 dengan 8 nilai.

\subsection{Pengujian Fan}

Pengujian fan dilakukan dengan cara memprogram arduino sehingga fan dapat berputar sesuai dengan hasil deteksi sensor. Hasil pengujian Fan dapat dilihat pada Tabel 4. 


Tabel 4 hasil pengujian Fan
\begin{tabular}{|c|c|c|}
\hline No & Fan & PPM \\
\hline 1 & ON & $>150$ \\
\hline 2 & OFF & $<150$ \\
\hline
\end{tabular}

Pengujian fan untuk menanggapi hasil deteksi dari sensor MQ-2 dan MQ-7 saat mendeteksi adanya kandungan gas atau asap maka fan akan berputar, setelah sensor sudah tidak mendeteksi adanya kandungan gas atau asap maka fan akan berhenti berputar.

\subsection{Pengujian Buzzer}

Pengujian buzzer dilakukan dengan cara memprogram arduino sehingga buzzer dapat berbunyi sesuai dengan hasil deteksi sensor. Hasil pengujian Buzzer dapat dilihat pada Tabel 4.

Tabel 5 hasil pengujian Buzzer

\begin{tabular}{|c|c|c|c|}
\hline No & Sensor & ON & OFF \\
\hline 1 & MQ-2 & $>150$ & $<150$ \\
\hline 2 & MQ-7 & $>150$ & $<150$ \\
\hline
\end{tabular}

Pengujian buzzer untuk menanggapi hasil deteksi dari sensor MQ-2 dan MQ-7 saat mendeteksi adanya kandungan gas maka buzzer akan berbunyi, setelah sensor sudah tidak mendeteksi adanya kandungan gas maka buzzer akan berhenti berbunyi.

\subsection{Pengujian Led}

Pengujian Led dilakukan dengan cara memprogram arduino sehingga Led dapat menyala sesuai dengan hasil deteksi sensor. Hasil pengujian Led dapat dilihat pada Tabel 6.

Tabel 6 hasil pengujian Led

\begin{tabular}{|c|c|c|c|}
\hline No & $\begin{array}{c}\text { Led } \\
\text { Merah 1 }\end{array}$ & $\begin{array}{c}\text { Led } \\
\text { Merah 2 }\end{array}$ & CO, Gas dan Asap \\
\hline 1 & ON & ON & Deteksi \\
\hline 2 & OFF & OFF & Tidak Deteksi \\
\hline
\end{tabular}

Pengujian Led untuk menanggapi hasil deteksi dari sensor MQ-2 dan MQ-7 saat mendeteksi adanya kandungan gas maka Led akan menyala, setelah sensor sudah tidak mendeteksi adanya kandungan gas maka Led akan berhenti menyala.

\subsection{Halaman Monotoring}

Pada gambar 8 terdapat Halaman Monitoring untuk mengakses data sensor.

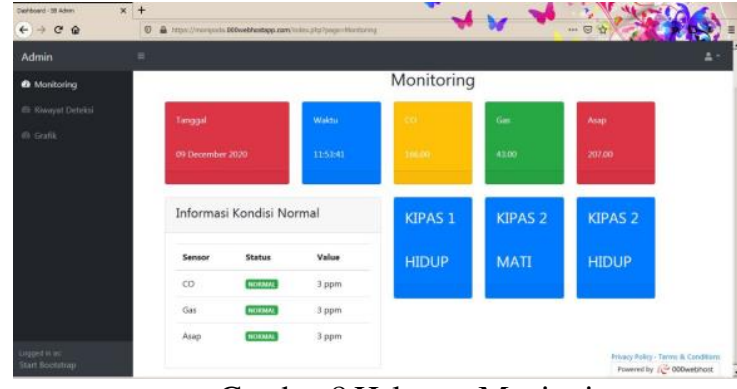

Gambar 8 Halaman Monitoring

Setelah pada Halaman Monitoring, dijlanjutkan pada Halaman Riwayat. Pada Halaman Riwayat akan ditampilkan riwayat deteksi dari database berupa tabel. Tanpilan Halayan riwayat pada Gambar 9.

\subsection{Halaman Riwayat}

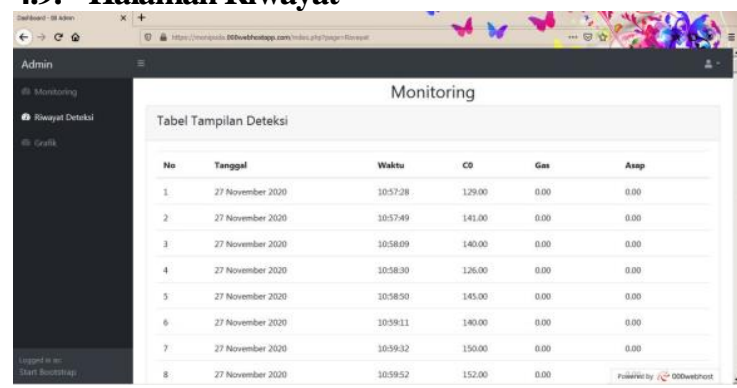

Gambar 9 Halaman Riwayat

\subsection{Halaman Grafik}

a. Grafik CO

Pada grafik CO, akan menampilkan nilai dari 30 data terakhir. Dengan nilai kadar CO tertinggi sebesar 188 ppm.

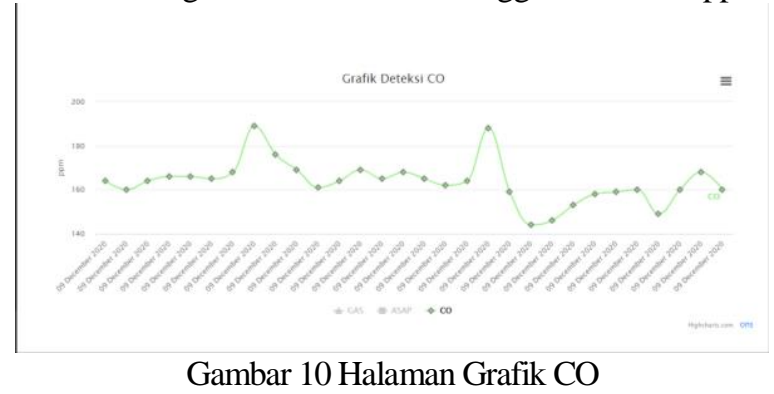

b. Grafik Gas

Pada grafik Gas, juga akan menampilkan nilai dari 30 data terakhir. Dengan nilai kadar Gas tertinggi sebesar 47 ppm.

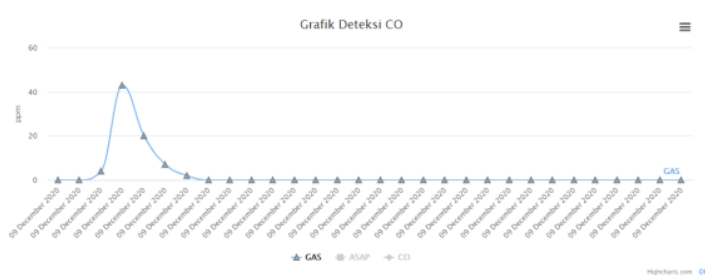

Gambar 11 Halaman Grafik Gas 


\section{c. Grafik Asap}

Pada grafik Asap, juga akan menampilkan nilai dari 30 data terakhir. Dengan nilai kadar Asap tertinggi sebesar 200 ppm.

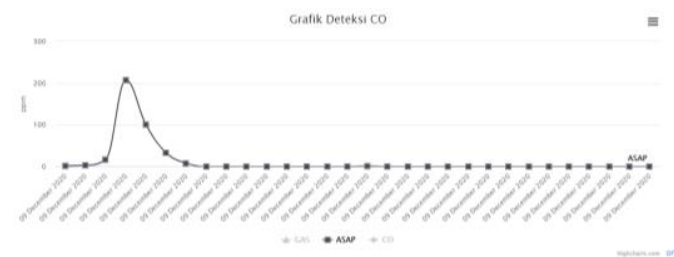

Gambar 12 Halaman Grafik Asap

\subsection{Pengujian Fungsional}

Tabel 7. Pengujian Fungsional

\begin{tabular}{|c|c|c|c|}
\hline \multirow[b]{2}{*}{ No } & \multirow[b]{2}{*}{ Aspek Pengujian } & \multicolumn{2}{|c|}{ Web Browser } \\
\hline & & $\begin{array}{l}\text { Chrome } \\
(87.0 .4)\end{array}$ & $\begin{array}{c}\text { Microsoft } \\
\text { Edge (44.1.1) }\end{array}$ \\
\hline 1 & $\begin{array}{l}\text { Tampilan data } \\
\text { sensor dan bar } \\
\text { data pada halaman } \\
\text { Monitoring }\end{array}$ & $\checkmark$ & $\checkmark$ \\
\hline 2 & $\begin{array}{l}\text { Tampilan data } \\
\text { Riwayat pada } \\
\text { halaman Riwayat }\end{array}$ & $\checkmark$ & $\checkmark$ \\
\hline 3 & $\begin{array}{l}\text { Tampilan } \\
\text { responsif pada } \\
\text { halaman } \\
\text { monitoring }\end{array}$ & $\checkmark$ & $\checkmark$ \\
\hline 4 & $\begin{array}{l}\text { Tampilan } \\
\text { responsif pada } \\
\text { halaman Riwayat }\end{array}$ & $\checkmark$ & $\checkmark$ \\
\hline 5 & $\begin{array}{ll}\text { Tampilan } & \text { dan } \\
\text { fungsi login } & \\
\end{array}$ & $\checkmark$ & $\checkmark$ \\
\hline
\end{tabular}

Keterangan :

$\checkmark$ : Berhasil

$\mathrm{x}$ : Tidak Berhasil.

Berdasarkan hasil uji coba pada tabel di atas bahwa website yang dibuat dapat berjalan dengan baik pada web browser Google Chrome (87.0.4), Microsoft Edge (44.1.1),mozilla firefox, dan Samsung Internet pada handphone. Semua fungsi dapat berjalan dengan baik. Oleh karena itu, fitur pada sistem monitoring yang dikembangkan dapat berjalan dengan baik pada web browser.

\subsection{Pengujian User}

Tabel 8 Pengujian User

\begin{tabular}{|c|l|c|c|}
\hline \multirow{2}{*}{ No } & \multicolumn{1}{|c|}{ Pertanyaan } & \multicolumn{2}{|c|}{ Jawaban } \\
\cline { 3 - 4 } 1 & $\begin{array}{l}\text { Ya } \\
\text { Apakah sistem monitoring gas } \\
\text { berbahaya dalam suatu ruangan } \\
\text { ini sudah memudahkan } \\
\text { pengguna memantau kondisi } \\
\text { sekitar? }\end{array}$ & 25 & - \\
\hline 2 & $\begin{array}{l}\text { Apakah tampilan antar muka } \\
\text { website monitoring ini mudah } \\
\text { dimengerti dan dioperasikan? }\end{array}$ & 24 & 1 \\
\hline 3 & $\begin{array}{l}\text { Apakah sistem monitoring ini } \\
\text { dapat berjalan dengan efektif? }\end{array}$ & 24 & 1 \\
\hline \multirow{2}{*}{4} & $\begin{array}{l}\text { Apakah sistem monitoring ini } \\
\text { dapat menanggulangi secara } \\
\text { cepat jika terjadi bahaya secara } \\
\text { dini? }\end{array}$ & 25 & - \\
\hline
\end{tabular}

\begin{tabular}{|c|l|c|c|}
\hline 5 & $\begin{array}{l}\text { Apakah sistem monitoring ini } \\
\text { dapat memantau kapan saja } \\
\text { dengan baik? }\end{array}$ & 23 & 2 \\
\hline & Total & $\mathbf{1 2 1}$ & $\mathbf{4}$ \\
\hline & Persentase & $\begin{array}{c}\mathbf{9 6 . 8} \\
\mathbf{\%}\end{array}$ & $\mathbf{3 . 2} \%$ \\
\hline
\end{tabular}

Berdasarkan hasil pengujian pada Tabel 8 diketahui mayoritas user menilai bahwa sistem monitoring polusi udara pada tanaman hidroponik sudah berjalan dengan baik. Oleh karena itu, sistem monitoring yang dikembangkan telah sesuai dengan harapan user.

\section{KESIMPULAN DAN SARAN}

\subsection{Kesimpulan}

Berdasarkan langkah - langkah yang dilaksanakan diketahui sistem monitoring polusi udara pada tanaman hidroponik dapat dikembangkan, dengan hasil pengembangannya sebagai berikut:

1. Dari hasil pengujian yang dilakukan pada sensor MQ-2 dan sensor MQ-7, diperoleh kadar gas, asap dan co paling tinggi pada tempat yang tertutup dengan rentang waktu pukul 12.00 siang -05.00 sore.

2. Dari hasil pengujian user, mayoritas user menilai bahwa sistem monitoring polusi udara pada tanaman hidroponik sudah berjalan dengan baik. Oleh karena itu, sistem monitoring yang dikembangkan telah sesuai dengan harapan user.

3. Dari hasil pengujian web browser, bahwa website yang dibuat dapat berjalan dengan baik pada web browser Google Chrome (87.0.4), Microsoft Edge (44.1.1), Mozilla Firefox, dan Samsung Internet pada smartphone. Semua fungsi dapat berjalan dengan baik. Oleh karena itu, fitur pada sistem monitoring yang dikembangkan dapat berjalan dengan baik pada web browser.

\subsection{Saran}

Berdasarkan keterbatasan penelitian dan hasil produk yang dikembangkan, penulis memberikan beberapa saran sebagai berikut :

1. Pengembangan dapat menambahkan fitur notifikasi deteksi sensor via Telegram / Whatsapp

2. Pengembangan dapat menambahkan sensor deteksi untuk mengetahui suhu dan kelembapan pada tanaman.

\section{DAFTAR PUSTAKA}

[1] Gupta, A., 2018. Effect of Air Pollutants on Plant Gaseous Exchange Process: Effect on Stomata and Respiration, 85-92.

[2] Singh, K., 2016. Pollution and Vegetable Contamination: A Review of the impact of various pollutants.

[3] Shoma, R. Z., 2020. PENERAPAN LOGIKA FUZZY UNTUK PENGENDALIAN KUALITAS UDARA PADA RUANGAN SMOKING AREA DENGAN 
MIKROKONTROLER.https://ejournal.itn.ac.id/ index.php/jati/article/view/2356

[4] Handayani, S., Hadiansa, A. \& Masrizal, 2017. RANCANGAN APLIKASI PENGUKUR TINGKAT POLUSI UDARA BERBASIS ARDUINO UNO R3 DAN WEB. https://www.ejurnal.stmik-budidarma.ac.id

[5] Karisma, A. I., Kurniawan, F. \& Hanani, A., 2019. Rancang Bangun Sistem Monitoring Environment Area Tempat Tinggal Mahasiswa Berbasis IoT. http://ejournal.uin-malang.ac.id

[6] Liandy, A., 2018. RANCANG BANGUN PEMANTAUAN GAS BERBAHAYA DAN SUHU PADA RUANGAN MELALUI WEBSITE BERBASIS ARDUINO. http://eprints.itn.ac.id/

[7] Putra, H. S. D., Lim, R. \& Putro, I. H., 2019. PEMANTAUAN KUALITAS UDARA POLUTAN GAS CO Dan CO2 BERBASIS IoT. http://jurnalelektro.petra.ac.id/
[8] Somayya, M., Ramaswamy, R. \& Tripathi, S., 2015. Internet of Things (IoT): A Literature. Journal of Computer and Communications, Volume III, pp. 164-173.

[9] Angela.G, S., 2016. A STUDY ON VARIATION IN PIGMENT CONTENT IN PLANTS UNDER AIR POLLUTION STRESS. International Journal of Advanced Technology in Engineering and Science, 4(8), pp. 533-537.

[10] Tania, M., 2017. Alat Pendeteksi Gas CO Menggunakan Sensor MQ-7 Berbasis Arduino. [Online] Available http://repositori.usu.ac.id/handle/123456789/386 2 [Accessed 2810 2020].

[11] Guntoro, H., Somantri, Y. \& Haritman, E., 2013. RANCANG BANGUN MAGNETIC DOOR LOCK MENGGUNAKAN KEYPAD DAN SOLENOID BERBASIS MIKROKONTROLER ARDUINO UNO. Elektro, Volume 12, pp. 3948. 